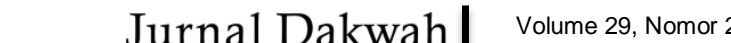 \\ Desember 2018 \\ P-ISSN: $1412-0348$ \\ E-ISSN: 2654-3877
}

\section{MARKETING POLITIK REKRUTMEN POLITISI PEREMPUAN DI PROVINSI RIAU \\ (Studi Kasus Partai Solidaritas Indonesia dan Partai Nasional Demokrat)}

\author{
Chelsy Yesicha \\ Jurusan Ilmu Komunikasi FISIP Universitas Riau \\ Email: chelsy.yesicha@lecturer.unri.ac.id
}

\section{Kata kunci \\ Citra, Marketing, Politisi Perempuan}

\section{Keywords}

Image Building, Marketing, Women Politician

\begin{abstract}
Abstrak
Meski Riau dinobatkan memiliki politisi perempuan terbanyak di parlemen periode 2014-2019 di Indonesia, partai tetap perlu melakukan marketing politik guna merekrut politisi perempuan di Pemilu 2019. Partai Solidaritas Indonesia dan Partai Nasional Demokrat merupakan partai yang berani mengusung tema "tanpa mahar" menjadi fokus kajian guna mengetahui image building dan media komunikasi yang digunakan dalam merekrut politisi perempuan di wilayah Riau. Pendekatan studi kasus jamak memperlihatkan perbedaan antara kedua partai dengan pengumpulan data yang digunakan yaitu wawancara, observasi dan dokumentasi akhirnya menyimpulkan bahwa Image Building Partai Solidaritas Indonesia Riau mengutamakan keterbukaan dan keinovatifan bagi mata rantai pengerak perempuan Riau untuk berpolitik sedangkan Partai Nasional Demokrat Riau menampilkan realitas "politik tanpa mahar" bagi partai melalui keberhasilannya, role model dihadirkan untuk mempengaruhi perempuan Riau dalam melaksanakan Restorasi Indonesia. Komunikasi bermedia yang dilakukan keduanya unggulan bertaut pada akun DPP dan interpersonal dinilai efektif dalam merekrut politisi perempuan Riau.
\end{abstract}

\begin{abstract}
Although Riau has the most female politicians in parliament in the 2014-2019 period in Indonesia, the party still needs to conduct political marketing to recruit female politicians in the 2019 election. The Indonesian Solidarity Party and the Democratic National Party are parties that dare to carry the theme "Tanpa Mahar" as the focus of the study in order to find out image building and communication media used in recruiting female politicians in the Riau region. The approach to plural case studies shows the difference between the two parties with data collection used, namely interviews, observation and documentation finally concluded that the Image Building Indonesia Solidarity Party Riau prioritized openness and innovation for the chain of drivers of Riau women to take part in politics while the Riau National Democratic Party presented the reality of "politics without dowry" for the party through its success, role models were presented to influence Riau women in implementing restraints $i$ Indonesia. Media communication carried out by both the linked seed on DPP and interpersonal accounts was considered effective in recruiting Riau female politicians.
\end{abstract}




\section{Pendahuluan}

Partisipasi politik perempuan tidak saja dilakukan dengan memberikan suara saat pemilihan umum (pemilu) namun melibatkan perempuan berpolitik menjadi satu bentuk demokratisasi perempuan menyuarakan aspirasi mereka, terutama dalam perjuangan hak perempuan dan hak anak. Partai politik yang bertindak sebagai agen demokrasi mempunyai tugas penyalur aspirasi dari konstituen dan mengubahnya menjadi kebijakan publik sehingga partai bertanggungjawab melaksanakan kegiatan kaderisasi melalui proses rekrutmen politik. Rekrutmen menjadi urat nadi bagi partai untuk mempersiapkan kader pemimpin dan generasi partai yang berpotensi. Dalam merekrut kader perempuan, banyak pihak yang menganggap bahwa hal ini sekadar pemenuhan syarat semata, hingga pada akhirnya menghiasi pertarungan politik saat pemilu.

Pengesahan Undang-Undang Pemilihan Umum No. 7 Tahun 2017 semakin mempertegas keleluasaan pergerakan perempuan dalam politik. Peraturan perundangan yang ramah terhadap perempuan lahir menjelang pemilu 2004 melalui Undang-Undang Nomor 12 Tahun 2003 tentang Pemilihan Umum. Pasal 65 ayat (1) Undang-Undang tersebut menyatakan bahwa setiap partai politik peserta Pemilu dapat mengajukan calon anggota DPR, DPRD Provinsi, dan DPRD Kabupaten/ Kota untuk setiap Daerah Pemilihan dengan memperhatikan keterwakilan perempuan sekurang-kurangnya $30 \%$. Empat tahun kemudian muncul UU Nomor 2 Tahun 2008 tentang Partai Politik yang menyebutkan bahwa kepengurusan partai politik di tingkat pusat, provinsi serta kabupaten/ kota disusun dengan memperhatikan keterwakilan perempuan paling rendah $30 \%$ yang diatur dalam AD dan ART partai. Hal ini dilakukan agar rekrutmen politik dan proses pengisian jabatan politik melalui mekanisme yang demokratis dengan memperhatikan keadilan dan kesetaraan gender.UU No 2 Tahun 2008 tersebut dibuat sejalan dengan lahirnya UU No. 10 Tahun 2008 yang menyebutkan bahwa penyertaan sekurang-kurangnya 30\% keterwakilan perempuan pada kepengurusan parpol tingkat pusat menjadi salah satu persyaratan parpol untuk dapat menjadi peserta pemilu dan daftar bakal calon peserta pemilu juga harus memuat paling sedikit 30\% keterwakilan perempuan. Posisi perempuan dalam politik semakin kuat dengan lahirnya UU No 8 Tahun 2012 yang menegaskan bahwa dalam setiap 3 (tiga) orang bakal calon, sekurangkurangnya 1 (satu) orang perempuan. Terakhir, menjelang Pemilu 2014 muncul Peraturan KPU Nomor 7 Tahun 2013 yang merupakan penegasan dari poin-poin yang ada pada peraturan-peraturan sebelumnya (Hartarti, 2014), dan UU No 7/2017, Pemilu 2019 Pasal 173: menyertakan paling sedikit 30\% keterwakilan perempuan pada kepengurusan partai politik tingkat pusat.

Dukungan lain membuka peluang perempuan ketika partai tersebut tanpa mahar, mengingat rumor yang berkembangan di masyarakat jika kita berpolitik harus memiliki mahar atau sebut saja modal kuat. Padahal sudah tercantum dalam undang-undang bahwasa dalam pendaftaran tidak dipungut biaya. Namun permainan lain terjadi di internal partai misalnya, persaingan nomor urut, sosialisasi caleg dan permainan oknum dalam partai politik sehingga momok bagi mereka untuk berpolitik. 
Dalam usaha rekrutmen kader politisi perempuan tentunya partai sudah mulai melakukan perjalanan marketing politik guna menjaring kader politisi demi mencetak rekor pemilih. Meski Riau dinobatkan memiliki politisi perempuan terbanyak yang duduk di parlemen periode 2014-2019 di Indonesia, partai tetap perlu melakukan marketing politik untuk merekrut politisi perempuan di pemilu 2019 nanti. Partai Solidaritas Indonesia dan Partai Nasional Demokrat merupakan partai yang berani mengusung tema "tanpa mahar" yang menjadi fokus kajian dalam penelitian ini, tujuannnya untuk mengetahui media komunikasi yang digunakan dalam merekrut politisi perempuan di wilayah Riau.

Politisi menurut Romelta dalam Herdrawati (2014) adalah pelaku politik yakni orang-orang yang terlibat langsung dalam kegiatan politik praktis, seperti pengurus/ aktivis partai politik, para pejabat negara, orang-orang yang duduk di lembaga pemerintahan. Perempuan adalah salah satu jenis manusia yang berpikir, berbaur, beraktivitas untuk memenuhi hak dan kewajibannya. sehingga politisi perempuan adalah kegiatan praktis perempuan dalam memenuhi hak dan kewajibannya di lingkungan politik.

Rekrutmen politik merupakan cara melakukan seleksi terhadap orang-orang yang akan menjadi pengurus partai politik, harus diubah dan lebih berorientasi pada masalah bangsa dan negara. Selain itu, proses pengkaderan dan muatan-muatan politis yang diberikan kepada mereka harus diubah. Perlu ditanamkan kesadaran bahwa mereka merupakan bagian dari bangsa dan negara, dan bahwa merupakan bagian dari bangsa dan negara bahwa dipundak mereka terdapat segudang permasalahan bangsa dan negara yang harus diselesaikan (Firmanzah, 2011).

Rekrutmen politik memegang peranan penting dalam sistem politik suatu negara karena proses ini menentukan orang-orang yang akan menjalankan fungsi-fungsi sistem politik negara itu melalui lembaga-lembaga yang ada. Oleh karena itu, tercapai tidaknya tujuan suatu sistem politik tergantung pada kualitas rekrutmen politik. Partai politik memiliki cara tersendiri dalam melakukan rekrutmen terutama dalam pelaksanaan sistem dan prosedural rekrutmen yang dilakukan partai politik tersebut. Tak hanya itu proses rekrutmen juga merupakan fungsi mencari dan mengajak orang-orang yang memiliki kemampuan untuk turut aktif dalam kegiatan politik, yaitu dengan cara menempuh berbagai proses penjaringan.

Pengertian rekrutmen adalah arena untuk membangun kaderisasi, regenerasi dan seleksi para kandidat serta membangun legitimasi dan relasi antara partai dengan masyarakat sipil (Herdrawati, 2014). Rekrutmen Politik adalah proses yang menarik dan mengajak orang untuk menjadi anggota partai politik dan aktif dalam kegiatan politik, Proses rekrutmen politik meliputi metode rekruitmen, sumber pengrekrutan dan cara seleksi sehingga anggota partai politik yang telah direkrut benar-benar berkualitas dan membawa kemajuan (Septian, 2014). Untuk itu partai perlu mengatur stategi marketing agar mendapatkan kader yang unggul. 
Marketing politik dapat meningkatkan kualitas proses demokratisasi di negara berkembang. Yang perlu diingat marketing politik merupakan sesuatu yang kontekstual (Firmanzah, 2008). Marketing politik merupakan aktivitas yang dilakukan oleh partai politik dan kontestan individu dalam merancang isu-isu yang akan dilempar ke masyarakat, mengomunikasikan solusi yang hendak diterapkan ketika berkuasa, ideologi partai dan kontrol sosial terhadap partai politik/individu yang berkuasa (Firmanzah, 2008). Secara umum, Heryanto (2013) mengelompokkan strategi marketing politik menjadi dua varian yaitu; strategi marketing politik media dan strategi marketing politik nonmedia. Media adalah sarana untuk mentransmisikan pesan dari sumber ke audiensi, (Sudaryono, 2016).

Marketing menggunakan media terbagi atas dua jenis media yaitu media massa dan nirmassa. Media nirmassa dibagi kedalam dua bentuk media, yaitu media kelompok dan media personal, pengertian media diungkapkan oleh disiplin ilmu lainnya terdapat beberapa perbedaan istilah, seperti dalam istilah ekonomi media dibagi atas dua, yaitu media dalam ruangan (indoor promotion) dan luar ruangan (outdoor promotion). Media yang termasuk outdoor di antaranya neon box, signboard, banner dan poster, sedangkan media indoor ada selebaran, faksimili dan surat. Marketing nonmedia adalah komunikasi yang dijalankan oleh personal selling yaitu antara sales dan konsumen yang biasa terjadi saat tatap muka. Dalam komunikasi pemasaran yang perlu diamati adalah sejauh mana komunikasi primer ini memberikan efek secara langsung atau tidak langsung terhadap tujuan dari marketing (Soemanagara, 2006).

Citra dalam entitas dan pemimpin politik yang serius bukanlah kombinasi yang kebetulan dari keadaan, sesuatu yang diberikan, sesuatu yang muncul dengan sendirinya, sebaliknya itu terencana dengan baik, pakar spesialis komunikasi yang mengurusnya, mereka mengidentifikasi karakteristik kunci dari citra dari entitas atau kandidat politik, mereka mengelola dengan mengembangkan dan memodifikasinya bila perlu (Sharlamanov, 2014).

Orzekauskas and Smaiziane (2007) indicate that according to Gee (2000) there are four levels of image building:

- Fundamental image, the first level of image building which includes the individual and the organizational principles, philosophies, objectives and standards of acting

- Internal image, includes planning and conducting of organization politics and activities directed towards the members of the political party in order to strengthen their loyalty to the party, as well as the party solidarity

- External image, includes the activities through which the politician and the political entity are presented in public, the building of appropriate relations with the media and the public is an entirety, the behavior of the politician or the political entity in public 
- Unattainable image, includes the influence of the behavior on the factors that are related to the politician or the political entity, their cultural matrix, education, motivation etc (Sharlamanov, 2014:601.

Tujuan marketing dalam politik adalah membantu partai politik untuk menjadi lebih baik dalam mengenal masyarakat yang diwakili atau yang menjadi target, kemudian mengembangkan program kerja atau isu politik yang sesuai dengan aspirasi mereka, dan mampu berkomunikasi secara efektif dengan masyarakat. Marketing politik juga bertujuan meraih kesuksesan bagi calon kandidat dalam pemilihan. Pertumbuhan marketing politik merupakan industry utama yang memengaruhi hampir setiap warga negara dan lembaga dalam kontestasi politik. Seorang kandidat, untuk menjadi sukses, harus memahami pasar mereka, para pemilih dan kebutuhan dasar mereka serta aspirasi dan konstituen yang mereka wakili atau mencari untuk mewakili (Heryanto, 2013).

\section{Metode}

Penelitian ini menggunakan metode kualitatif dengan pendekatan studi kasus jamak (collective or multiple case study) yaitu, yang menggunakan banyak/ lebih dari satu isu atau kasus di dalam satu penelitian. Menurut Yin dalam Pujileksono (2015) peneliti studi kasus jamak ini, dapat menggunakan suatu prosedur sama yang dilakukan untuk setiap isu/ kasus. Di akhir penelitian akan disampaikan perbedaan Partai Nasional Demokrat (Partai Nasdem) dan Partai Solidaritas Indonesia (PSI) dalam rekrutmen politisi perempuan Riau menjelang persiapan pemilu 2019. Teknik pengumpulan data yang digunakan yaitu wawancara, observasi dan dokumentasi. Wawancara langsung secara snowball, dan observasi dilakukan pada informan penelitian sedangkan dokumentasi dan observasi digunakan sebagai pendukung data disesuaikan dengan kebenaran yang didapatkan. Adapun informan dalam penelitian ini: Bro Raja Juli Antoni (Sekjen PSI), Bro Kartono (Ketua DPP PSI Kota Pekanbaru), Sis Febri Yenti dan Sis Ella Winara (caleg perempuan dari PSI Riau). Sedangkan dari Partai Nasdem Riau Rusdaryanto sebagai Humas Partai Nasdem Riau dan Farida H. Saad Politisi Perempuan Nasdem 2014-2019.

\section{Hasil dan Pembahasan}

\section{Image Building dan Media yang Digunakan Partai Solidaritas Indonesia (PSI) dalam Rekrutmen Politisi Perempuan}

Image building yang digunakan partai baru ini sangat menarik dimana mereka menggunakan sapaan bro dan sis di dalam komunitas partai. Partai ini lebih menampilkan kehangatan dalam menyambut para calon politisi untuk memberikan pendidikan politik sekaligus berdiskusi. Representasi dengan cara yang muda bijak dan rasional lebih mereka bangun dengan cara yang elegan dan optimis. Partai Solidaritas Indonesia ini mulai dikenal dengan partai perempuan karena beranggotakan 6 orang perempuan dari 9 total pengurus pusat partai. Secara tegas disampaikan bahwa PSI 
sendiri berdiri menjadi mata rantai pergerakan perempuan Indonesia perlunya affirmative action seperti perdebatan $30 \%$ pengurus perempuan di kalangan partai. Image partai tanpa mahar yang disampaikan dalam pemberitaan selama ini merupakan sebuah strategi bagi partai sekaligus memberikan keleluasaan pada perempuan dalam ikut berpolitik, "tanpa mahar" merupakan salah satu strategi. Karena selain politik transparansi bergabung dalam politik karena memungkinkan perempuan untuk bergabung dalam politik karena dengan kultur kita yang sangat buruk dengan perempuan. Bro Raja menyampaikan bahwa menggeluarkan uang kita untuk politik makin masalah untuk di perempuan. Positioning partai muda "tanpa mahar" sendiri diakui oleh pengurus partai telah mereka relisasikan dalam pengurusan syarat-syarat administrasi pendaftaran calon legislative bahkan bantuan dana meski tidak sepenuhnya. Bagi bakal calon legislative perempuan PSI Riau yang umumnya bukan sebagai politisi pemula dukungan keluarga menjadi sebuah motivasi yang berharga guna mewujudkan tekad.

PSI Riau menyesuaikan dengan motto mereka "Terbuka, Progresif Itu Kita!" dalam merekrut politisi perempuan mereka menggunakan trik tanpa mahar. Sebagai partai baru dan peduli perempuan, politisi perempuan PSI memiliki peluang besar untuk terpilih. Baginya sudah seharusnya perempuan-perempuan Riau akan dikenal di tingkat nasional oleh karenanya perempuan harus berpolitik.

PSI merupakan partai yang sedang memupuk diri melalui popularitas mereka. Berdasarkan pengamatan peneliti, partai anak muda ini mulai melakukan pergerakan mereka di Kota Pekanbaru saat menjelas Idul Fitri dengan memajang spanduk ucapkan pimpinan pengurus partai dibeberapa titik wilayah Pekanbaru. Di media televisi PSI sudah menayangkan iklan melalui sayap partai Perkumpulan Solidaritas Indonesia (PSI) di televisi nasional swasta mulai akhir Juni 2018. PSI menampilkan dua jenis iklan dengan pesan yang membangun harapan dan motivasi bagi semua pihak. Berikut hasil telusur dari peneliti.

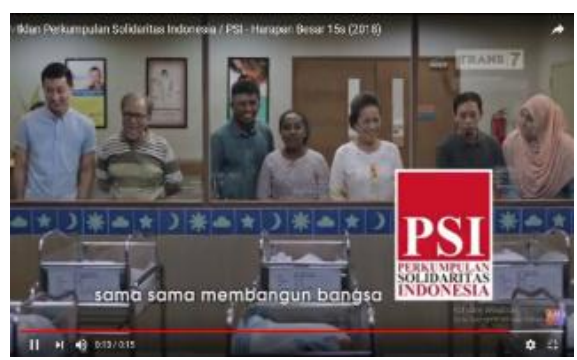

Gambar 1. Iklan PSI 1

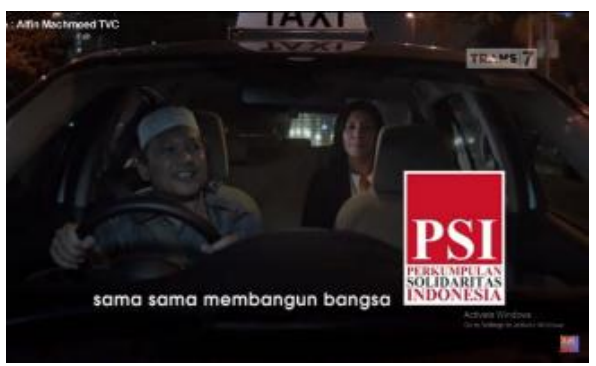

Gambar 2. Iklan PSI 1

Dokumentasi : Sumber Youtube Akun PSI (Diakses 25 Juli 2018)

Media sosial yang digunakan oleh PSI adalah Instagram, Facebook, Twitter, dan Youtube. Peneliti juga melakukan observasi pada tanggal 14 Juli 2018 melalui media 
sosial yang sama bahwa khusus Riau yang memiliki akun Instagram dan selalu aktif adalah @psi_meranti.

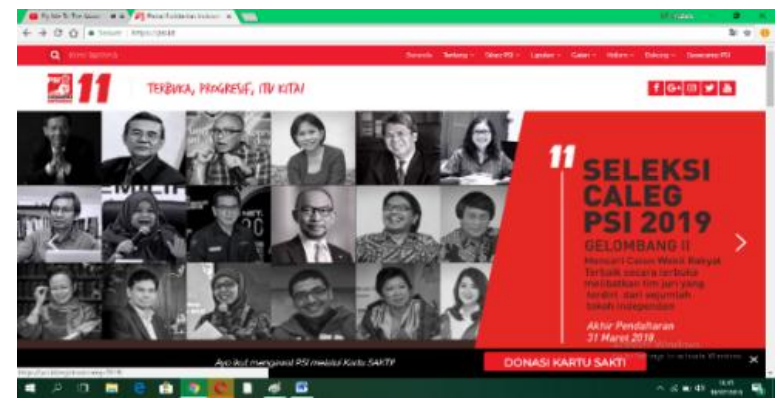

Gambar 3. Situs Web PSI

Media sosial PSI menjadi partai yang paling aktif, sesuai dengan segmentasi dan anggota mereka yang berasal dari kaum milenial sehingga partai ini disebut juga dengan "Partai Sosial Media Indonesia". Bro Raja sendiri menyampaikan bahwa marketing media sosial seperti Instagram @ psi_id dilakukan cara membuat video-video yang menyentuh terhadap perempuan dan mengajarkan perlunya perempuan berpolitik. Jargon iklan di televisi baru yang digunakan "sama-sama punya harapan sama-sama bangun bangsa".

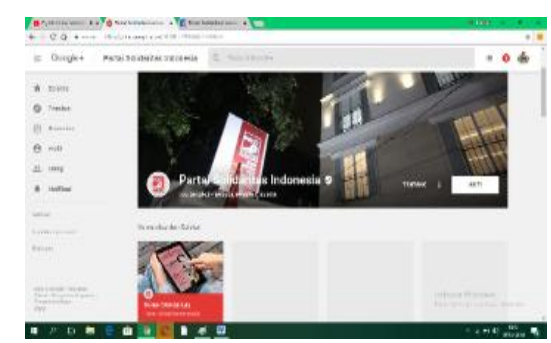

Gambar 4. Akun Google Plus PSI

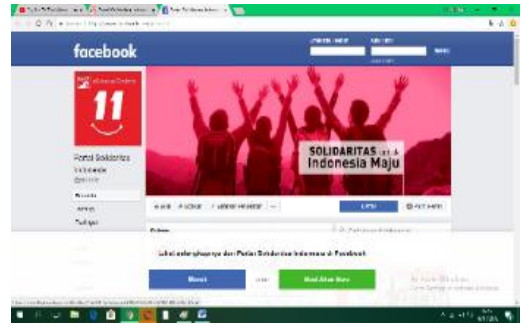

Gambar 5. Akun Facebook PSI

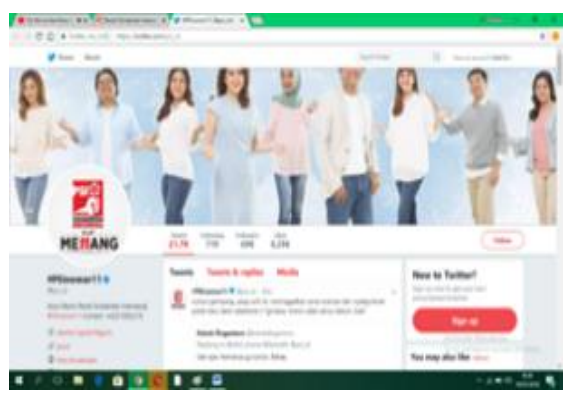

Gambar 6. Akun Twitter PSI

PSI Riau menggunakan media luar ruang seperti bendera billboard, spanduk juga menjadi komponen penting sebagai identitas basecamp PSI. Atribut lain seperti baju kaos atau merchandise yang lain digunakan dalam melaksanakan sosialisasi KOPDAR BACALEG dan persuasi ke calon legislatif juga mereka berikan kepada masyarakat. 
Media luar ruang yang mereka gunakan berupa: bendera, pakaian yang menampilkan identitas partai.

\section{Image Building dan Media Komunikasi yang Digunakan Partai Nasional Demokrat dalam Rekrutmen Politisi Perempuan}

Dalam proses pengrekrutan politisi perempuan, Partai Nasdem melakukan dua tahapan: melalui jalur internal dan eksternal. Partai membidik khususnya untuk merekrut kader perempuan Nasdem tidak harus berpedoman pada kader internal, tapi mencari yang benar-benar memiliki kemampuan dan potensi dari caleg perempuan sendiri baik itu melalui sayap-sayap partai partai seperti Garda Wanita (Garnita). Sayap partai adalah organisasi masyarakat yang dibentuk bernaung dalam Partai Nasdem. Eksternal partai, "Nasdem Memanggil" secara terbuka. Rekrutmen eksternal ini membutuhkan waktu yang panjang. Cara persuasi yang digunakan tim Nasdem mendatangi bakal caleg dan mereka yang datang sendiri untuk bergabung.

Kecenderungan yang tampak lebih efektif bagi Partai Nasdem dalam merekrut adalah dari eksternal partai dengan cara "jemput bola". Cara ini dinilai efektif dan elegan karena Nasdem melakukan hal tersebut dengan menurunkan tim khusus beranggotakan mayoritas perempuan. Ada beberapa tokoh perempuan dari Nasdem yang didatangi dan diposisikan nominator anggota, kemudian dimasukkan dalam nominator unggulan. Mereka bukan saja berasal dari struktur DPW tetapi juga dari sayap partai seperti Garnita. Untuk eksternal Nasdem menumbuhkan rasa etis dan menghormati sehingga yang didatangi merasa terhormat dan dihargai, tertarik dengan ajakannya.

Partai Nasdem Riau sebelumnya berhasil meraih satu kursi yang diwakili perempuan pada pemilu tahun 2014. Ia dijadikan role model partai dalam merekrut anggota bakal calon legislatif perempuan pada pemilu 2019. Saat ini, Farida A. Saad menjadi petahana dari daerah Pemilihan Kabupaten Meranti. Sebagai legislator di provinsi, ia "turun" ke masyarakat untuk menyemangati perempuan Riau. Ia ke daerahdaerah untuk memberikan pemahaman tentang politik bagi kader-kader perempuan.

Keberhasilan dan popularitas partai menjadi salah satu kunci kemudahan bagi mereka dalam merekrut calon anggota legislatif. Partai tidak terlalu digesa dengan rekrutmen karena banyak di antara bakal calon yang justru datang dan menawarkan diri untuk bergabung, baik mereka yang akan pindah maupun yang akan memulai karier di bidang politik. "Politik Tanpa Mahar" yang secara transparan gencar dilakukan oleh Nasdem melalui media menjadi daya tarik bagi calon untuk bergabung.

Penerapan "Politik Tanpa Mahar" merupakan bagian dalam Restorasi Indonesia yang diusung oleh Partai Nasdem sejak awal. Realisasi rekrutmen tanpa mahar justru mengusung komponen potensi politisi perempuan dalam membangun visi misi. Pemenuhan kuota $30 \%$ perempuan di masing-masing daerah pemilihan menarik perhatian partai untuk selektif dan turun langsung mencari "jemput bola". Mereka mendapatkan masukan informasi dari masyarakat ataupun anggota partai yang 
kemudian ditindak lanjuti dengan melakukan komunikasi persuasif kepada anggota tersebut. Partai Nasdem juga melakukan road show untuk menarik perhatian masyarakat dalam menjaring bakal caleg.

Pada pemilu 2019 ini, Partai Nasdem memperlihatkan kematangan mempersiapkan diri dalam merekrut politisi khususnya memulai dari internal, melalui sayap-sayap partai yang selama ini menjadi pendukung Partai Nasdem. Melalui eksternal partai, Partai Nasdem mendapatkan informasi baik dari masyarakat maupun anggota yang kemudian melakukan persuasif dengan cara "jemput bola". Tim rekrutmen juga mengajak anggota legislatif terpilih turun langsung ke masyarakat untuk menyemangati perempuan-perempuan di daerah dan memberikan pemahaman tetang politik bagi kader-kader perempuan. Pihak eksternal juga mendapatkan perhatian dari calon yang datang langsung untuk bergabung Partai Nasdem.

Roadshow juga menjadi event internal mereka untuk mensosialisasikan pengrekrutan Partai Nasdem ke sejumlah kabupaten dan kota se-Riau. "Politik Tanpa Mahar" dan "Nasdem Memanggil Putra Putri Terbaik" menjadi pesan yang memikat bagi bakal caleg. Keduanya merupakan program Partai Nasdem dalam Restorasi Indonesia.

Partai Nasdem menggunakan media komunikasi interpersonal dalam merekrut politisi perempuan. Istilah "jemput bola" menjadi salah satu strategi yang paling efektif. Mereka juga menggunakan jejaring untuk mendapatkan calon yang diinginkan melalui anggota maupun masyarakat sekitar. Tentunya ajakan politik tanpa mahar menjadi salah satu daya tarik khusus dalam menggaet calon. Pendidikan menjadi unsur utama yang mereka tetapkan dalam persyaratan.

Tahun 2019, menjadi tahun kedua bagi Partai Nasdem. Hal ini bukan menjadi sesuatu yang sulit bagi partai ini untuk membangun popularitasnya. Sebut saja ketua umum mereka Surya Paloh yang menjadi pemilik media televisi berita swasta pertama di Indonesia. Sosialisasi yang dilakukan Partai Nasdem melalui media ini cukup menancapkan peluru di kepala pemirsa. Untuk daerah, mereka tidak terlalu sulit untuk membangun nama Partai Nasdem dalam sosialisasi saat melaksanakan jemput bola. Mengingat partai ini telah terlebih dahulu bertarung pada pemilu 2014.

Mengenai marketing media yang digunakan dalam rekrutmen politisi, berdasarkan pengamatan tim peneliti, Partai Nasdem memajang baliho di beberapa titik secara strategis di Pekanbaru secara continu sejak tahun 2011. Billboard rekrutmen "Politik Tanpa Mahar" dimulai awal tahun 2017 dan dilanjutkan dengan "Nasdem Memanggil Putra-Putri Terbaik" di 2017.

Berdasarkan penelusuran, Metro TV dan web resmi Partai Nasdem merupakan sarana utama Partai Nasdem dalam melaksanakan sosialisasi partai untuk merekrut calon legislatif 2019 mencakup seluruh wilayah yang ada di Indonesia, berikut tampilannya: 


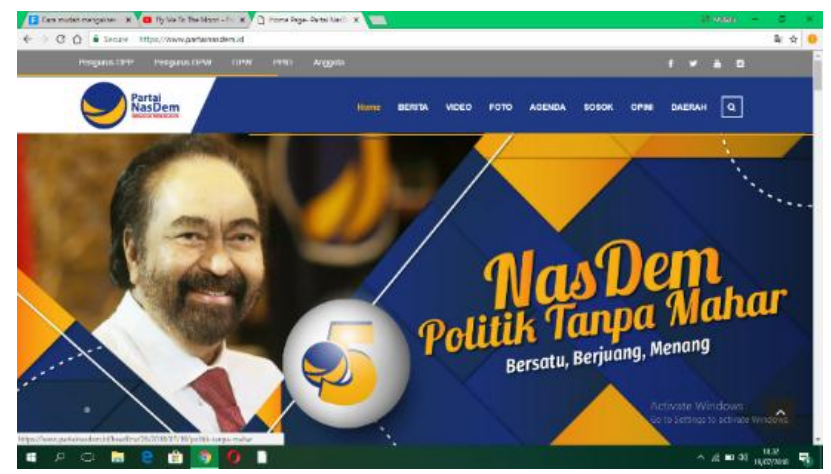

Gambar 7. Situs Wab Partai Nasdem

Media sosial merupakan media yang juga digunakan oleh Partai Nasdem merujuk kepada akun dari media sosial dari Dewan Perwakilan Pusat Partai Nasdem Demokrat. Berikut ini adalah hasil observasi.

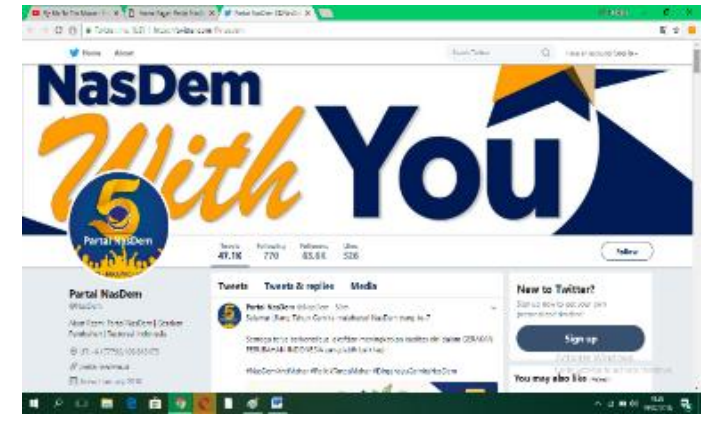

Gambar 8. Akun Twitter Partai Nasdem

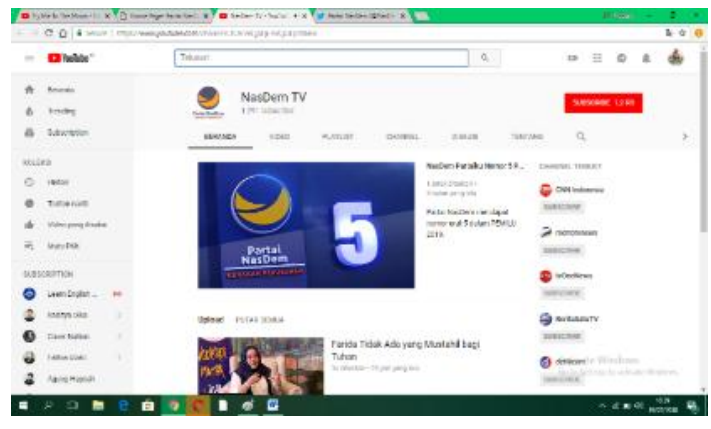

Gambar 9. Akun Youtube Partai Nasdem

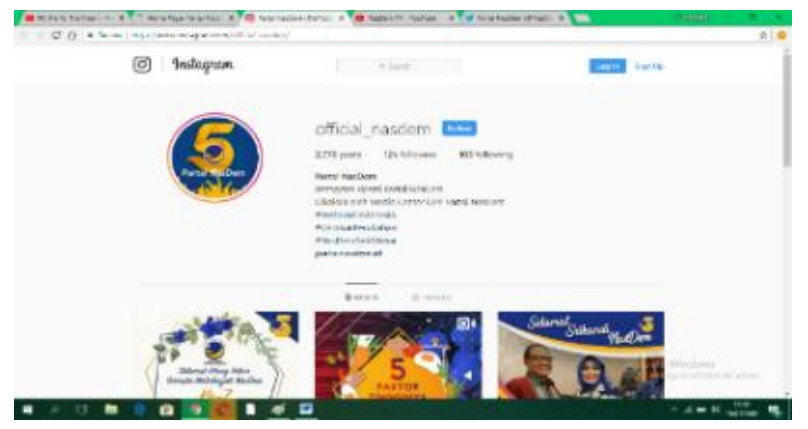

Gambar 11. Akun Instagram Partai Nasdem

Khusus Partai Nasdem Riau menggunakan media cetak lokal. Media luar ruang seperti baliho, billboard, spanduk juga menjadi komponen yang tidak bisa dihindari oleh Partai Nasdem. Atribut lain seperti baju, kaos atau merchandise digunakan dalam melaksanakan roadshow dan persuasi ke calon legislatif serta mereka berikan kepada masyarakat. 


\section{Diskusi}

Dari penelitian ini, peneliti menemukan level fundamental image: Sebagai partai baru, PSI menggunakan motto mereka “Terbuka, Progressive, Itu Kita!” Membuka cakrawala para calon kader yang akan berkecipung di dalamnya. Keterbukaan tidak hanya bermaksud dalam transparansi, tanpa mahar namun juga membangun solidaritas dari berbagai suku, agama dan status. Tanpa mahar menjadi satu keberanian untuk menarik perhatian politisi perempuan untuk berpolitik selagi tekad dan keberanian yang tumbuh dalam diri mereka. Sedangkan Partai Nasdem tahun ini merupakan perekrutan gelombang kedua dengan mengusung tagline yang sama yaitu: "Politik Tanpa Mahar". Politik Tanpa Mahar merupakan bagian dari Restorasi Indonesia yang menjadi motto mereka.

Level internal image, Partai Solidaritas Indonesia (PSI) hadir dengan menebarkan seribu pesona untuk menggaet kaum milenial baik dari pengurus, kader hingga target pemilihnya bukan hanya pemilih muda dalam pemilu 2019. Mereka tidak khawatir untuk menjaring kader hingga calon legislatif muda dan belum berpengalaman dalam dunia politik. Dengan menampung aspirasi dan kreativitas anak muda, PSI memperlihatkan daya tarik tersendiri bagi mereka yang berumur lebih dari 40 tahun untuk bergabung ke PSI, bukan karena usia namun mempertahankan jiwa muda.

PSI tampil sebagai partai ramah perempuan bukan hanya karena mayoritas keanggotaan mereka di pusat adalah perempuan, namun perlunya perubahan pandangan kultur perempuan dijadikan subjek dalam politik. PSI sebagai mata rantai pergerakan perempuan dalam berpolitik. Dalam satu kesempatan mereka membagikan stroller bagi kaum ibu sebagai bentuk kepedulian mereka. Partai Nasdem merekrut politisi perempuan dengan membidik kemampuan dan potensi yang dimiliki kader baik internal melalui sayap-sayap partai terlebih dahulu. Perekrutan eksternal juga dilakukan secara luas dan terbuka selanjutnya partai akan mempertimbangkan potensi dan elektabilitas nominator. Dalam perekrutan baik secara internal maupun eksternal, Partai Nasdem merealisasikan restorasi dalam tubuh internal partai mereka melalui politik tanpa mahar.

Level eksternal image, PSI menghadirkan keinovatifan di mata masyarakat terutama kaum perempuan sehingga memiliki peluang besar bagi mereka untuk bergabung dan berkompetisi secara positif pada pemilu 2019. Berbeda dengan kepercayaan diri yang dimiliki Partai Nasdem, "Nasdem Memanggil Putra Putri Terbaik" semakin mempertegas eksistensi partai. Partai Nasdem baru memulai kompetisi tahun 2014 namun keberhasilan mendapatkan 1 kursi anggota legislatif perempuan periode 2014-2019 di tingkat provinsi. Ini mengukuhkan Partai Nasdem di Riau dalam memikat perempuan untuk berpolitik.

Level unattainable image, kedua partai ini berbuat untuk Riau, dengan melakukan persuasi melalui pengurus partai atau kader memotivasi perempuan daerah untuk mengajak perempuan Riau berpolitik. Dalam sejarah belum ada perempuan Riau yang dikenal sebagai pahlawan nasional. PSI yakin dapat memberikan warna tersendiri dalam kehidupan perempuan Riau untuk menjadi pahlawan nasional. Untuk itu perempuan 
perlu berpolitik. Partai Nasdem sendiri memiliki cara dengan menggunakan role model mereka yaitu anggota legislatif terpilih untuk menyemangati perempuan daerah yang memiliki potensi untuk bergabung dalam partai.

Secara umum, pengelompokkan strategi marketing politik menjadi dua varian yaitu; strategi marketing politik media dan strategi marketing politik nonmedia (Heryanto, 2013). Kedua partai ini melakukan perekrutan secara terbuka. Strategi marketing politik nonmedia yang dilakukan keduanya secara interpersonal dan bersifat persuasif, tindakan tersebut bukan hanya langsung dari internal partai saja melainkan sesama bacaleg. Hal yang tidak jauh berbeda dilakukan oleh Partai Nasdem yaitu mengadakan roadshow ke sejumlah kabupaten dan kota di Provinsi Riau dan membagibagikan merchandise.

Strategi media yang digunakan PSI adalah media sosial yang selalu aktif melalui video-video yang menyentuh perempuan yaitu Instagram dan Youtube. Ini menjadi andalan PSI sejak awal. Akun @psi_meranti sebagai perwakilan dari Riau sedangkan DPW PSI Riau sendiri lebih banyak aktif di Facebook. PSI juga meletakkan bendera merah dan backdrop partai di luar sekretariat. PSI baru menggunakan media luar ruang di Kota Pekanbaru menjelang Idul Fitri $1438 \mathrm{H}$, internal partai menggunakan papan ucapan selamat di beberapa titik. Pada Mei 2018 PSI mulai menghadirkan dua iklan televisi.

Strategi marketing politik media Partai Nasdem telah lama dilakukan. Media luar ruang merupakan media tetap yang digunakan oleh partai seperti baliho dan billboard yang tetap ditampilkan di beberapa titik di kawasan strategis Kota Pekanbaru. Untuk perekrutan, spanduk "Partai Nasdem Memanggil Putra Putri Terbaik" juga dipasang di setiap kantor sekretariat partai. Begitu juga denga media cetak lokal. Sedangkan media online website Partai Nasdem Riau bertaut dengan Partai Nasdem Pusat.

\section{Simpulan}

Marketing politik merupakan sebuah upaya besar dalam menyakinan berbagai macam pihak untuk dapat merebut perhatian dan kepercayaan masyarakat, baik masyarakat luas maupun mereka yang berminat berkecimpung dalam kontestasi politik tahun 2019. Masing masing mengeluarkan berbagai jurus dan pesona dalam merekrut politisi, terutama kaum perempuan yang menjadi syarat mutlak dalam pemilu nanti.

Image building yang digunakan dalam rekrutmen politisi perempuan, PSI Riau hadir dengan mengutamakan keterbukaan dan keinovatifan yang memberikan peluang besar bagi politisi muda, bernilai ramah perempuan guna menggugah calon menjadi mata rantai pengerak perempuan Riau untuk berpolitik. Sedangkan Partai Nasdem Riau lebih menampilkan realitas politik tanpa mahar bagi internal maupun eksternal partai melalui keberhasilannya. Role model dihadirkan untuk mempengaruhi perempuan Riau dalam melaksanakan Restorasi Indonesia.

Strategi komunikasi bermedia yang dilakukan keduanya masih unggul dengan bertaut pada akun website resmi maupun akun media sosial Dewan Pimpinan Pusat 
(DPP). Akun @psi_meranti aktif berselancar dengan menampilkan video-video di Instagram dengan tautan dari akun @PSi_id dan youtube, sedangkan PSI Riau lebih aktif di akun Facebook. Dalam komunikasi nonmedia, kedua partai menggunakan persuasi langsung secara interpersonal, yang dinilai efektif dalam merekrut politisi perempuan Riau. Keunggulan Partai Nasdem juga menggunakan roadshow dan pemasangan billboard secara berkelanjutan di sejumlah titik di Kota Pekanbaru, semakin memperlihatkan kematangannya menuju pemilu 2019.

\section{Referensi}

Firmanzah. 2008. Marketing Politik: Antara Pemahaman dan Realitas. Jakarta: Yayasan Obor Indonesia.

Heryanto, G.G. \& Rumaru, S. (2013). Komunikasi Politik Suatu Pengantar. Jakarta: Ghalia Indonesia.

Pujileksono, S. (2015). Metode Penelitian Komunikasi Kualitatif, Malang: Intrans Publishing.

Septian, D. (2014). Rekrutmen Politik Dalam Penetapan Calon Legislatif (Studi Kasus DPD Partai Golongan Karya Kota Tanjungpinang) Jurusan Ilmu Pemerintahan DISIP Universitas Raja Ali Haji.

Sharlamanov, K. \& Jovanoski, A. (2014). The Role of Image in the Political Campaigns, International Journal of Scientific \& Engineering Research, 5 (6).

Soemanagara. (2006). Strategic Marketing Communication "Konsep Strategis Dan Terapan". Bandung: Alfabeta.

Sudaryono. (2016). Manajemen Pemasaran Teori Dan Implementasi. Yogyakarta: Penerbit Andi. 